\title{
Antarctic network of lamp-calibrated multichannel radiometers for continuous ozone and uv radiation data
}

\author{
A. Redondas ${ }^{1}$, C. Torres ${ }^{1}$, O. Meinander ${ }^{2}$, K. Lakkala ${ }^{2}$, R. García ${ }^{1}$, E. Cuevas ${ }^{1}$, \\ H. Ochoa ${ }^{3}$, G. Deferrari ${ }^{4}$, and S. Díaz ${ }^{4}$ \\ ${ }^{1}$ Instituto Nacional de Meteorología, Izaña Atmospheric Research Center, Spain \\ ${ }^{2}$ Finnish Meteorological Institute, Helsinki, Finland \\ ${ }^{3}$ Dirección Nacional del Antártico, Instituto Antártico Argentino, Buenos Aires, Argentina \\ ${ }^{4}$ Centro Austral de Investigaciones Científicas, Ushuaia, Argentina
}

Received: 3 January 2008 - Accepted: 9 January 2008 - Published: 18 February 2008

Correspondence to: A. Redondas (aredondas@inm.es)

Published by Copernicus Publications on behalf of the European Geosciences Union.

\begin{abstract}
Three NILU-UV multichannel radiometers have been installed in 1999 at the Argentinian sites of Ushuaia (54S), Marambio (64S) and Belgrano-II (77S) in order to continuously monitor UV radiation, photosynthetically active radiation and total ozone. The 5 measurements were established by INM, Spain in collaboration with FMI, Finland, DNA-IAA, Argentina and CADIC, Argentina to observe and characterize the spatial and temporal evolution of ozone and ultraviolet radiation in the Antarctic region. Special attention has been given to the quality control and quality assurance of the measurements under harsh climatological conditions. The ozone and UV time series of 10 2000-2006 were calibrated using a polynomial fit for lamp measurements performed every second week all year round. The gaps in these data are minimal, with almost no data missing, and the data products are available from http://www.polarvortex.org in near real time. The data products include the erythemally-weighted UV, UVB and UVA radiation, photosynthetically active radiation (PAR), total ozone $\left(\mathrm{O}_{3}\right)$ and a cloud 15 parameter (CLT). For UV data, dose rates as well as daily doses are available; from these the maximum measured UV indices (UVI), during 2000-2006, were 12.0, 9.7 and 8.1 at Ushuaia, Marambio and Belgrano-II, respectively.
\end{abstract}

\section{Introduction}

Due to climate change, the expected recovery of the stratospheric ozone layer (Had20 jinicolaou et al., 2005; Weatherhead and Andersen, 2006) may be endangered, as changes in the climate may serve to cool the stratosphere to temperatures favourable for ozone depletion (Butchart et al., 2000). All the factors that affect UV radiation, i.e., ozone, clouds, albedo (especially the effect of snow cover) and aerosols are related to climate change. Continuous quality- controlled Antarctic measurements of total ozone and UV radiation are therefore of great importance. It is evident that the ozone depletion area is variable and changes from year to year (WMO (World Meteorological 
Organization), 2007).

The Spanish contribution to Antarctic research began with the installation of three UV-VIS spectrometers at the Argentinian bases of Belgrano-II, Marambio and Ushuaia in 1994; in 1999 ozone soundings for the INTA (Instituto Nacional de Técnica Aeroes5 pacial, Spain) were started at Belgrano-II, as well as the installation of three radiometers for the INM (Instituto Nacional de Meteorología, Spain), at the above-mentioned stations thanks to the existing agreements on scientific collaboration between the DNA/IAA (Dirección Nacional del Antártico/Instituto Antártico Argentino, Argentina) and INTA and INM, respectively. These complementary and coordinated networks 10 of instruments are intended to observe and characterise the spacial and temporal evolution of the $\mathrm{O}_{3}, \mathrm{NO}_{2}, \mathrm{OClO}$ and ultraviolet radiation in these regions during coming years. This project will provide and unique information to other Spanish and international groups involved in Antarctic biology research (Parrondo et al., 2007; Steck et al., 2007; Yela et al., 2003). The observation data are accessible to researcher at the web

15 http://www.spain.oracle-o3.org.

In order to monitor the ozone profiles of the Antarctic, an Argentinian-Finnish cooperation project initiated regular ozone soundings at Marambio in November 1988. Nowadays they make a significant contribution to the regular ozone depletion reports, ozone bulletins, compiled by the WMO (http://www.wmo.ch/pages/prog/arep/ 20 gaw/ozone/), and have been used in scientific research (Taalas et al., 1997). The sounding data are available to all researchers from the data bases of WOUDC (World Ozone and UV radiation Data Center) and NILU (Norwegian Institute for Air Research). Since 1999, the ozone-hole-related activities at Marambio have been enlarged into Spanish-Argentinian-Finnish co-operative project, as it became one of the three yeararound Antarctic region stations to measure simultaneously total ozone and UV radiation with NILU-UV multichannel filter radiometers.

Previously, in 1988, NSF (U.S. National Science Foundation) had established a measurement network comprising six high-latitude sites from the South Pole to Alaska (Bernhard et al., 2005). The NSF network in the Antarctic region includes Ushuaia

3385

$\left(54^{\circ} 49^{\prime} \mathrm{S}, 68^{\circ} 19^{\prime} \mathrm{W}\right)$, McMurdo $\left(77^{\circ} 50^{\prime} \mathrm{S}, 166^{\circ} 40^{\prime} \mathrm{E}\right)$, Palmer $\left(64^{\circ} 46^{\prime} \mathrm{S}, 64^{\circ} 03^{\prime} \mathrm{W}\right)$, and the South Pole $\left(90^{\circ} 00^{\prime} \mathrm{S}\right)$. NSF sites are equipped with scanning spectroradiometers (type SUV-100 or SUV-150B) and multichannel filter instruments (type GUV511 or GUV-541). The NSF observations are freely available via the internet at 5 http://www.biospherical.com/NSF/.

The Antarctic NILU-UV network by the Spanish-Finnish-Argentinian co-operative project is unique in the sense that no earlier UV network has linked the Antarctic and the European Arctic. The NILU-UV network travelling reference of FMI, described further in Sect. 2.2, can be used to compare and transfer the UV irradiance scale from 10 one hemisphere to another. In addition to this, the station of Ushuaia belongs to both the NSF and our network. This makes solar comparisons possible, and all the stations of both of networks can be used for any study with knowledge of the irradiance scales. According to Lakkala et al. (2005), the irradiance scales of NSF and our network are within $5 \%$.

15 The ozone and UV data from the NILU-UV network, documented here for the first time, are quality-controlled, continuous and have the potential for wide use among scientists. Recently, the results of the network were also used for the WMO ozone bulletin for the first time. The quality assurance of the network has been published earlier in Lakkala et al. (2005).

\section{NILU-UV antarctic network}

In 1999, an Antarctic network of multichannel NILU-UV instruments was established in order to measure real-time ground-based UV radiation and total ozone columns. The network was established by INM in collaboration with FMI, DNA-IAA and CADIC (Centre for Scientific Research, Argentina). The main objectives of the network are to 25 observe and to characterise the spatial and temporal evolution of both the ozone and the ultraviolet radiation in the Antarctic region and to carry out dynamics studies of the Antarctic polar vortex. At the present time, the network has been consolidated, and 
this makes it possible to analyse how the daily evolution of the vortex affects the ozone and UV radiation. Great effort has been put into the quality control of the network data so that they can also be used for studies that require high accuracy in the data, e.g., climatological studies.

\section{$5 \quad 2.1$ Stations}

NILU-UV multichannel filter radiometers have been set up at three Argentinian Antarctic stations. The location of the stations with respect to the stratospheric polar vortex, and to the ozone depletion area, is the underlying motive for selecting the sites: Belgrano-II $\left(77^{\circ} 52^{\prime} 29^{\prime \prime} \mathrm{S}, 34^{\circ} 37^{\prime} 37^{\prime \prime} \mathrm{W}, 50 \mathrm{~m}\right.$ a.s.l. $)$ is mostly located inside the vortex; Marambio $10\left(64^{\circ} 14^{\prime} \mathrm{S}, 56^{\circ} 38^{\prime} \mathrm{W}, 200 \mathrm{~m}\right.$ a.s.l.) is at various times inside, on the edge of, or outside the vortex; while Ushuaia $\left(54^{\circ} 49^{\prime} \mathrm{S}, 68^{\circ} 19^{\prime} \mathrm{W}, 50 \mathrm{~m}\right.$ a.s.I.) is mostly outside the vortex. All these bases are permanent and manned all the year round. At all the stations, the NILU-UV radiometers are installed on the roofs of the permanent buildings of the bases.

15 The Argentinian city of Ushuaia is the southernmost city in the world, and is located on Grande Island of the Land of the Fire. Ushuaia is affected by the Antarctic ozone loss, especially during an event in which it is beneath the vortex, and for this reason it is one of the most populated towns affected by the yearly ozone loss. Ushuaia is the capital of the Land of the Fire, and it extends over the slopes of the Martial Mounts. The measurement instruments are in the facilities of the CADIC. This Center was created on the 9 of April, 1969, and belongs to the National Council of Scientific and Technical Research (CONICET). In Ushuaia, the weather is variable all year round, with the lowest daily mean temperature of $1^{\circ} \mathrm{C}$ occurring at the end of July and beginning of August.

25 Marambio and Belgrano-II are two of the six Argentinian bases that remain open all year long, and belong to IAA-DNA. They were set up in 1969 and 1979, respectively. Marambio is located on the Island of Seymour, approximately $1.6 \mathrm{~km}$ to the NE of the Island of Cerro Nevado on the southern margin of the gulfs of Erebus and Terror in 3387

the Sea of Weddell. This base is located on a plateau $14 \mathrm{~km}$ in length and $8 \mathrm{~km}$ wide, $200 \mathrm{~m}$ a.s.l., and hosts many other scientific instruments, e.g., for carrying out regular ozone soundings and aerosol measurements. Sometimes the air masses there originate in midlatitudes and have high total ozone column values, while at other times 5 polar air masses with only little ozone affect the area. Belgrano-II is located in Nunatak Bertrab, on the Confin Coast (Land of Coast), Sea of Weddell. Because of its location, this base is one of the most important observatories for the study of the ozone destruction during the austral spring, but it is only accessible once a year, during the austral summer, and then only with the aid of the "Icebreakers Almirante Irizar". The weather

10 at Belgrano-Il is harsh. The wind may reach $200 \mathrm{~km} / \mathrm{h}$, and the measured maximum and minimum temperatures range from $-2^{\circ} \mathrm{C}$ to $-4^{\circ} \mathrm{C}$. Due to the high latitude, the sun does not rise at all for 4 months of the year.

\subsection{Instrument}

The NILU-UV 6T radiometer is a filter instrument with five UV channels, with central 15 wavelengths at around $305,312,320,340$ and $380 \mathrm{~nm}$, and bandwidths of around $10 \mathrm{~nm}$ at full-width half-maximum (FWHM). A sixth channel measures the photosynthetic active radiation (PAR) in the $400-700 \mathrm{~nm}$ wavelength region. The radiometer has a Teflon diffuser, silicon detectors, high-quality bandpass filters and is temperaturestabilized to $40^{\circ} \mathrm{C}$. One-min averages of measured irradiances and detector tempera-

20 tures are recorded. The measurements can be used to retrieve UV-B, UV-A, erythemally -weighted UV radiation and the total ozone column, as well as to provide cloudiness information, using the method described by Dahlback (1996). The characteristics of the instrument are described in more detail in Höiskar et al. (2003).

During the period 2000-2006, the NILU-UV \#012 and NILU-UV \#011 radiometers 25 have been measuring continuously at Ushuaia and Marambio, respectively, while at the Belgrano-II base, three different instruments have been used for measurements: NILU-UV \#009, NILU-UV \#010 and NILU-UV \#023 (Table 1). Due to technical problems during the exchange of instruments in Belgrano-II, the NILU-UV\#023 has been 


\subsection{Quality control (QC) and Quality assurance (QA)}

The quality control and quality assurance of the network is based on regular lamp measurements and, for UV radiation measurements, on a travelling reference (Lakkala et

5 al., 2005). An important part of the quality control has been to train the station operators; this training is repeated every second year. The operators perform daily checks that include timing control and cleaning of the diffuser. The levelling of the instrument is also regularly checked. The operators perform lamp tests and dark current measurements, as well as solar comparisons between the station instrument and the travelling 10 reference NILU-UV radiometer.

\subsubsection{Lamp measurements: QC}

The quality control for the site instruments consists of $100 \mathrm{~W}$ OSRAM Radium lamp measurements and dark current measurements. Two lamps are measured every two weeks and a third lamp is measured on every third calibration to exclude possible lamp drift. During the calibration, the power supply of the lamp is controlled with software that keeps the lamp intensity constant. Lamp tests are also made before and after each solar comparison to determinate the stability of the reference NILU.

In order to study the stability of the NILU-UV, the lamp measurement time series for each instrument was calculated. The normalized averages of lamp measurements at

20 Ushuaia, Marambio and Belgrano (2000-2006) are shown in Fig. 1. The results of all the six channels of the radiometer are shown. In each case, the lamp averages were normalized with the first calibration, in order to observe any changes in the sensitivity of the channels.

When we have four successive instruments at one station, as at Belgrano-II, it is 25 not always is possible to perform a direct comparison of the two instruments being interchanged. In this case, the last lamp calibration of the leaving instrument and the

first lamp calibration of the replacing instrument are used to adjust the calibration scales of the instruments. As the instruments are manufactured using the same filter batch, we convert the measurements of the lamps for each instrument to that of the other one before it. In this way, all calibrations are referenced to the first instrument NILU-UV 5 \#009 and a unique lamp series is used for all the NILU-UV radiometers at Belgrano-II.

Changes of more than $50 \%$ in the sensitivity of some of the channels have been observed in all the instruments. The channels with the largest drift are \#3 and \#4 in all the radiometers. To obtain the UV dose rates and ozone, the observed values have been corrected for the drift of the channels. The procedure used is shown in Sect. 3 10 and its validation using ozone measurements from different sources was described in Torres et al. (2002).

\subsubsection{Travelling reference: $\mathrm{QA}$}

The quality assurance of the UV measurements of the whole network is based on a travelling reference NILU-UV which makes it possible to maintain the absolute irradi-

15 ance scale of the different stations. The irradiance scale can be transferred using the results of solar comparisons between the reference NILU-UV and the NILU-UV of the station (Lakkala et al., 2005). The travelling reference visits Ushuaia three times and Marambio twice during the spring-summer-autumn season. Visits of the travelling reference to Belgrano-II are impossible, due to the inaccessibility of the site for most of the 20 year. Access is possible, using an icebreaker, only during the summer, when the NILUUV at Belgrano is replaced each year by another, well-calibrated, NILU-UV, of which the calibration is traceable to the irradiance scale used at Marambio and Ushuaia.

The travelling reference is calibrated every year or every second year. During the winter period of the Antarctic, the reference NILU-UV measures in the Arctic, and may 25 attend intercomparison campaigns. This makes possible the comparison of UV measurements performed in both hemispheres using the same irradiance scale. Table 2 shows the ratios between the erythemally-weighted UV dose rates retrieved from the reference NILU-UV, network NILU\#012 and those measured by the NSF-network SUV- 
spectroradiometer at Ushuaia. The results are shown for the lowest SZA in almost clear-sky conditions. A cosine correction of $5 \%$ has been assumed for the SUV-data (Bernhard, G., personal communication, 2004). The results show compatibility within the measurement uncertainties. The reference instrument for the calibration of the

5 reference NILU-UV is the Bentham spectroradiometer of the NRPA, whose irradiance scale is traceable to the National Institute of Standards and Technology (NIST) via the laboratory of SP, the Swedish National Testing and Research Institute (Johnsen et al., 2002). The irradiance scale of the SUV-spectroradiometer is also traceable to the NIST via $200 \mathrm{~W}$ lamps (Bernhard et al., 2006).

\section{Measurements}

The total ozone column and the biologically-effective UV rates are determinate using the method described by Dahlback (1996).

The total ozone column $(\Omega)$ is determined by comparing a calculated irradiance ratio, $\left(N^{\prime}\right)$, with the corresponding measured ratio $(N)$, Eq. (1),

${ }_{15} \mathrm{~N}(\theta, \Omega)=\operatorname{Vi}(\theta, \Omega) / \operatorname{Vj}(\theta, \Omega)$

where $V i$ and $V j$ are the irradiances in two channels with a different sensitivity to ozone absorption. We have used the ratio between the irradiances at $320 \mathrm{~nm}(\mathrm{Vi})$ and $312 \mathrm{~nm}$ $(\mathrm{Vj})$, low and high ozone absorption, respectively. A radiative-transfer model (Mayer and Kylling, 2005) is used to determine a look-up table of ratio $N^{\prime}$ as a function of solar

20 zenith angle $(\theta)$ and ozone $(\Omega)$. The look-up table also depends on the atmosphere, ozone profile, aerosols, clouds and surface albedo.

The UV dose rates $(D)$, Eq. (2), are determined as a linear combination of the irradiances, represented by the NILU-UV raw data $\left(V_{i}\right)$ obtained from the five UV channels (i).

${ }_{25} D=\sum_{i=1}^{5} a_{i} V_{i}$

In order to obtain the coefficients of the linear combination $\left(a_{i}\right)$, spectroradiometerbased calibration and radiative-transfer calculations are needed (Dahlback, 1996).

To apply this method, it is necessary to correct the drift shown by the quality control. A polynomial fit is calculated with the normalized average of lamp measurements to ob-

5 tain a daily correction coefficient for each channel and instrument (Fig. 1). With these coefficients, all the raw data are referenced to the first absolute calibration. This first calibration of all the network instruments was performed by the manufacturer at the Izaña Atmospheric Observatory, Izaña (Tenerife, Spain), in 1999. Following that, NILUUV \#012, NILU-UV \#011 and NILU-UV \#009 were set up at Ushuaia, Marambio and

10 Belgrano-II, respectively. All measurements are referenced to the first instrument NILUUV \#009 at Belgrano-II and all the other instruments are converted to this standard. The drift is corrected using its normalized lamp average, as at the other stations. With this correction method all the three stations maintain the scale of the manufacturer calibration; this absolute scale can be changed using the travelling reference in Ushuaia

15 and Marambio and in Belgrano we can use the NILU\#023 compared with QASUME unit (Gröbner et al., 2005) just before its setup at Belgrano as is described by Meinander et al. (2004).

\section{Results and discussion}

\subsection{Ozone and UV time series}

20 As the NILU-UV instrument gives a reading every min, it is perfect for monitoring rapid changes in the atmosphere. The total ozone changes during a day can be followed, as well as the exact UV daily doses, even during days with rapidly-changing cloudiness. The time series of 2000-2006 covers almost all the days of the year, with a minimal amount of missing data.

25 The total ozone and maximum daily UV index time series are shown in Fig. 2 for Ushuaia, Marambio and Belgrano-II. The connection between the total ozone and UV 
radiation is clearly seen in the time series. Maximum spring-time UV values are mostly connected with low ozone values. The daily evolution of the stratospheric polar vortex can also be studied from our measurements. The location of the polar vortex and its associated low ozone values can move from day to day and have an effect even at

5 the latitudes of Ushuaia. This event is usually recorded as high UV values at Ushuaia. During 2000-2006, the highest UV index value measured at Ushuaia was 12.0 on 27 Nov 2003. For the same period the highest UV index at Marambio was 8.1 on 04 Dec 2001 and 9.7 in Marambio on 22 Oct 2000.

The UV daily doses at three stations are shown in Fig. 3 during spring-time the 10 daily doses are similar, even though the latitude of Marambio and Belgrano would suggest significantly lower UV daily doses comparing with Ushuaia. High daily doses are strongly connected to low ozone values at Marambio and low cloudiness at Belgrano. The monthly means of erythemally-weighted UV daily doses are shown in Table 3.

\subsection{Web site implementation}

15 The NILU-UVs at the bases are controlled by individual workstations, in which the raw data are stored. The raw data are remotely harvested from the logging computers, and all data products are calculated and presented on the webpage http://www. polarvortex. org as soon as they are available. These data available from the web are thus realtime data and are considered to be provisional. Any user of the data is kindly asked o contact the web-master to get the latest QC/QA information. Two types of data are available for downloading: daily course data (of ozone, UVI, CIE, UVA, UVB, UVA/UVB CLT, PAR ) and summary files with the solar noon data. For both, two data versions, $\mathrm{V} 1.1$ and $\mathrm{V} 1.2$ exist, depending on the last available lamp test. V1.1 contains data extending up to the last-available stability check, while V1.2 is produced when the data has been processed using both the previous and the following lamp test. V1.1 is updated daily and V1.2 every two weeks after the lamp test has been performed.

\section{Conclusions}

In this paper we have presented the Antarctic NILU-UV network established in 1999 as a joint Spanish-Finnish-Argentinian co-operation. Three NILU-UV multichannel radiometers have been installed at the sites of Ushuaia, Marambio and Belgrano-II. Spe5 cial attention has been given to the quality control and quality assurance of the data. Initial and refresher training is provided for the operators, and regular lamp tests are performed in order to monitor the stability of the instruments. Severe drift of the channels of the multifilter radiometers has been detected and corrected in order to produce homogenized time series. The time series contain daily UV and ozone data since 2006 10 and are available online at http://www.polarvortex.org. The data contain UVB, UVA, erythemally-weighted UV dose rates, PAR and cloud information, and ozone data. Daily summaries of UV data are also available.

It is of major importance to continue long-term measurements of ozone and UV in the Antarctic region; extension of the existing valuable data series will enable monitoring

15 of future changes of all the relevant environmental factors, and ensure the availability of these data to the research community representing various fields of science. We have found the NILU-UV radiometer to be a good instrument for operation in harsh environments, but that $\mathrm{QA} / \mathrm{QC}$ are essential to monitor the drift in the sensitivity of the channels. In the future, we plan to include the Norwegian Troll station $\left(72^{\circ} 0^{\prime} \mathrm{S}, 2^{\circ} 32^{\prime} \mathrm{E}\right)$

20 in the network and its data in the web pages.

Acknowledgements. The MAR Project is financed by the National R\&D Plan of the Spanish Ministry of Science and Technology (National Research Program in the Antarctic) under contract REN2000-0245-C02-01.The Academy of Finland has given financial support for this work (FARPOCC -project). The SUV-spectroradiometer UV data from Ushuaia were provided

25 by the NSF UV Monitoring Network, operated by Biospherical Instruments Inc. under a contract from the United States National Science Foundation's Office of Polar Programs via the Raytheon Polar Services Company. We are grateful to B. Johnsen of the Norwegian Radiation Protection Authority for relative response measurements and fruitful discussions. We thank the operators of the NILU-UV Antarctic Network. 


\section{References}

Bernhard, G., Booth, C. R., and Ehramjian, J. C.: Real-time ultraviolet and column ozone from multichannel ultraviolet radiometers deployed in the national science foundation's ultraviolet monitoring network, Opt. Eng., 44, 1011-1012, 2005.

5 Bernhard, G., Booth, G. R., Ehramjian, J. C., and Quang, V. V.: Nsf polar programs uv spectroradiometer network 2003-2004 operations report, United States, National Science Foundation/Biospherical Instruments Inc, San Diego, CA, 2006.

Butchart, N., Austin, J., Knight, J. R., Scaife, A. A., and Gallani, M. L.: The response of the stratospheric climate to projected changes in the concentrations of well-mixed greenhouse gases from 1992 to 2051, J. Climate, 13, 2142-2159, 2000.

Dahlback, A.: Measurements of biologically effective uv doses, total ozone abundances, and cloud effects with multichannel, moderate bandwidth filter instruments, Appl. Optics, 35, 6514-6521, 1996

Gröbner, J., Schreder, J., Kazadzis, S., Bais, A., Blumthaler, M., Garts, P., Tax, R., Koskela,

15 T., Seckmeyer, G., Webb, A., and Rembges, D.: Traveling reference spectroradiometer for routine quality assurance of spectral solar ultraviolet irradiance measurements, Appl. Optics, 44, 5321-5331, 2005.

Hadjinicolaou, P., Pyle, J. A., and Harris, N. R. P.: The recent turnaround in stratospheric ozone over northern middle latitudes: A dynamical modeling perspective, Geophys. Res. Lett., 32, L12821, doi:10.1029/2005GL022476, 2005.

Höiskar, B., Haugen, R., Danielsen, T., Kylling, A., Edvardsen, K. R., Dahlback, A., Johnsen, B. R., Blumthaler, M., and Schreder, J.: Multichannel moderate-bandwidth filter instrument for measurement of the ozone-column amount, cloud transmittance, and ultraviolet dose rates, Appl. Optics, 42, 3472-3479, 2003.

25 Johnsen, B., Mikkelborg, O., Dahlback, A., Høiskar, B. A., Kylling, A., Edvardsen, K., Olseth, J. A., Kjeldstad, B., and Ørbæk, J.: Quality control of the norwegian uv monitoring network, EGS XXVII General Assembly, Nice, 21-26 April 2002, abstract \#1576, 27, 1576, 2002.

Lakkala, K., Redondas, A., Meinander, O., Torres, C., Koskela, T., Cuevas, E., Taalas, P., Dahlback, A., Deferrari, G., Edvardsen, K., and Ochoa, H.: Quality assurance of the solar uv

30 network in the antarctic, J. Geophys. Res., 110, D15101, doi:10.1029/2004JD005584, 2005.

Mayer, B. and Kylling, A.: Technical note: The libradtran software package for radiative transfer calculations - description and examples of use, Atmos. Chem. Phys., 5, 1855-1877, 2005,

3395

http://www.atmos-chem-phys.net/5/1855/2005/.

Meinander, O., Koskela, T., Lakkala, K., and Redondas, A.: Antarctic nilu-uv network linked to qasume and nsf irradiance scales, in: XX Quadrennial Ozone Symposium, Kos, Greece, 1128-1129, 2004.

5 Parrondo, M. C., Yela, M., Gil, M., von der Gathen, P., and Ochoa, H.: Mid-winter lower stratosphere temperatures in the antarctic vortex: Comparison between observations and ecmwf and ncep operational models, Atmos. Chem. Phys., 7, 435-441, 2007, http://www.atmos-chem-phys.net/7/435/2007/.

Steck, T., von Clarmann, T., Fischer, H., Funke, B., Glatthor, N., Grabowski, U., Höpfner, M.,

10 Kellmann, S., Kiefer, M., Linden, A., Milz, M., Stiller, G. P., Wang, D. Y., Allaart, M., Blumenstock, T., von der Gathen, P., Hansen, G., Hase, F., Hochschild, G., Kopp, G., Kyrö, E., Oelhaf, H., Raffalski, U., Marrero, R., Remsberg, E., Russell, J., Stebel, K., Steinbrecht, W., Wetzel, G., Yela, M., and Zhang, G.: Bias determination and precision validation of ozone profiles from mipas-envisat retrieved with the imk-iaa processor, Atmos. Chem. Phys., 7 , 3639-3662, 2007, http://www.atmos-chem-phys.net/7/3639/2007/.

Taalas, P., Damski, J., Kyr, E., Ginzburg, M., and Talamoni, G.: Effect of stratospheric ozone variations on uv radiation and on tropospheric ozone at high latitudes, J. Geophys. Res., 102, 1533-1540, 1997.

20 Torres, C., Redondas, A., Cuevas, E., Lakkala, K., and Taalas, P.: Correction and validation of total ozone data series from an antarctic multichannel filter radiometer solar uv network, EGS XXVII General Assembly, Nice, France, 21-26 April 2002, abstract\# 6222, 27, 2002.

Weatherhead, E. and Andersen, S.: The search for signs of recovery of the ozone layer, Nature, 441, 39-45, 2006.

25 WMO (World Meteorological Organization): Scientific assessment of ozone depletion, Geneva,Switherland Global Ozone Research and Monitoring Project-50, 572 pp., 2007.

Yela, M., Parrondo, C., Rodr, S., Gil, M., Araujo, J., Ochoa, H., Diaz, S., Deferrari, G., and Reimer, E.: The 2002 antarctic vortex splitting as observed from visible spectroscopy and ozonesoundings, EGS - AGU - EUG Joint Assembly, Abstracts from the meeting held in Nice, France, 6-11 April 2003, abstract\# 9093, 2003. 
Table 1. NILU-UV radiometers set up in the Base Belgrano-II.

\begin{tabular}{lll}
\hline Instruments & Date & Date \\
\hline NILU-UV \#009 & $02 / 03 / 2000$ & $26 / 02 / 2001$ \\
NILU-UV \#010 & $27 / 02 / 2001$ & $23 / 02 / 2002$ \\
NILU-UV \#009 & $24 / 02 / 2002$ & $25 / 02 / 2003$ \\
NILU-UV \#010 & $25 / 02 / 2003$ & $03 / 02 / 2004$ \\
NILU-UV \#023 & $04 / 02 / 2004$ & To present \\
\hline
\end{tabular}

3397

Table 2. The ratios of erythemally-weighted UV dose rates between the reference NILU-UV \#008 the network NILU-UV \#012 and the SUV-spectroradiometer at Ushuaia during 20002006.

\begin{tabular}{llll}
\hline Date & SZA & SUV/NILU \#008 & SUV/NILU \#012 \\
\hline $01 / 12 / 1999$ & 34 & 0.95 & \\
$15 / 02 / 2000$ & 40 & 0.97 & 1.04 \\
$06 / 05 / 2000$ & 70 & 1.03 & 1.07 \\
$27 / 10 / 2000$ & 40 & 0.99 & 0.96 \\
$09 / 02 / 2001$ & 40 & 0.98 & 1.04 \\
$18 / 05 / 2001$ & 74 & 0.99 & 1.08 \\
$17 / 10 / 2001$ & 34 & 0.98 & 0.96 \\
$14 / 04 / 2002$ & 65 & 0.97 & 1.01 \\
$11 / 11 / 2002$ & 40 & 0.97 & \\
$22 / 02 / 2003$ & 45 & 0.96 & 1.01 \\
$17 / 10 / 2003$ & 45 & 0.99 & 1.01 \\
$16 / 01 / 2004$ & 52 & 0.95 & 1.00 \\
$10 / 12 / 2004$ & 40 & 0.96 & 0.94 \\
$01 / 03 / 2005$ & 48 & 1.03 & 1.01 \\
$28 / 11 / 2005$ & 38 & 0.96 & 0.96 \\
$03 / 03 / 2006$ & 48 & 0.97 & 0.92 \\
$15 / 11 / 2006$ & 40 & 0.99 & 0.94 \\
\hline
\end{tabular}


Table 3. Monthly mean Erithemal Daily Dose $\left(\mathrm{KJ} / \mathrm{m}^{2}\right)$ for the three stations, even thoungth with the different latitude of the stations the values are comparable and even higher on the southermost station Belgrano.

\begin{tabular}{lccc}
\hline Month & $\begin{array}{c}\text { Ushuaia } \\
(54 \mathrm{~S})\end{array}$ & $\begin{array}{c}\text { Marambio } \\
(64 \mathrm{~S})\end{array}$ & $\begin{array}{c}\text { Belgrano } \\
(77 \mathrm{~S})\end{array}$ \\
\hline Jan & 3.1 & 2.6 & 2.7 \\
Feb & 2.5 & 1.7 & 1.5 \\
March & 1.3 & 0.8 & 0.4 \\
April & 0.5 & 0.2 & 0.1 \\
May & 0.2 & 0.0 & - \\
June & 0.1 & 0.0 & - \\
July & 0.1 & 0.0 & - \\
Aug & 0.3 & 0.2 & 0.1 \\
Sep & 1.0 & 1.0 & 0.5 \\
Oct & 2.0 & 2.0 & 2.0 \\
Nov & 2.7 & 2.5 & 3.0 \\
Dec & 3.3 & 2.8 & 3.1 \\
\hline
\end{tabular}
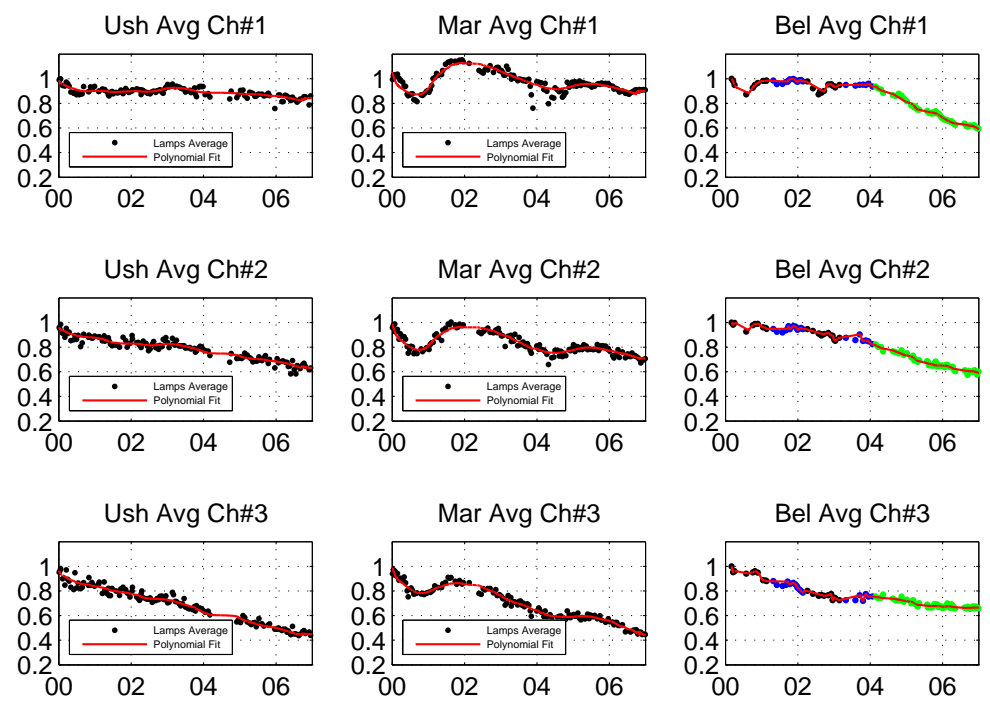

Fig. 1. Lamp measurements time series of Ushuaia, Marambio and Belgrano during 20002006. Results of the six channels are shown together with the average of the lamps and the polynomial fit. The colors in Belgrano series indicate the different instrumetns used. 

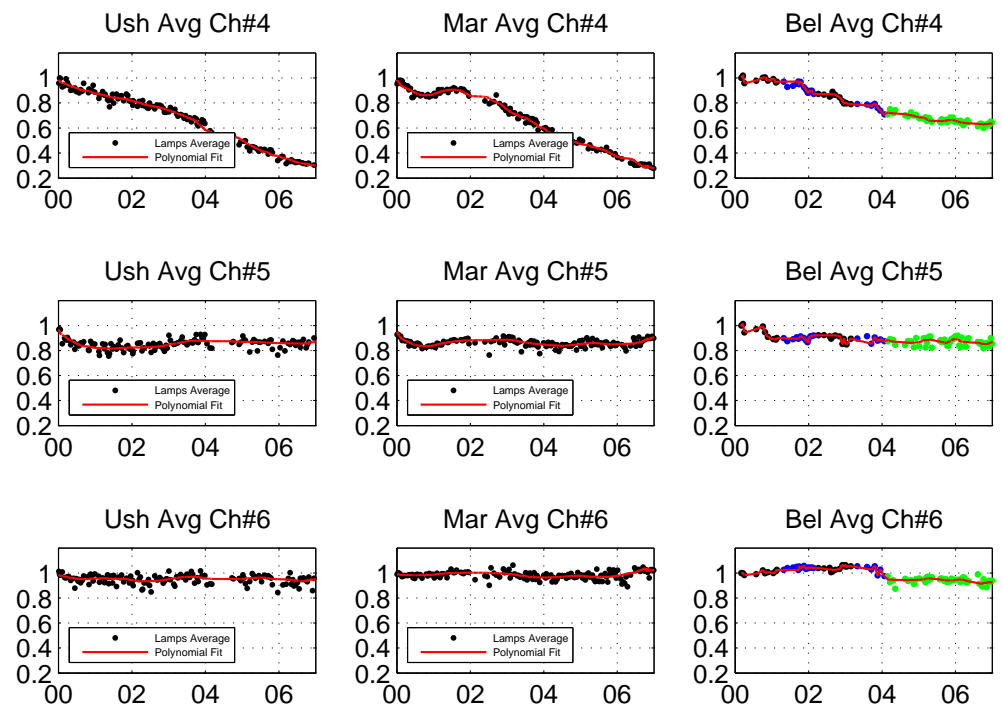

Fig. 1. Continued.

Total Ozone at Local Solar Noon:Ushuaia

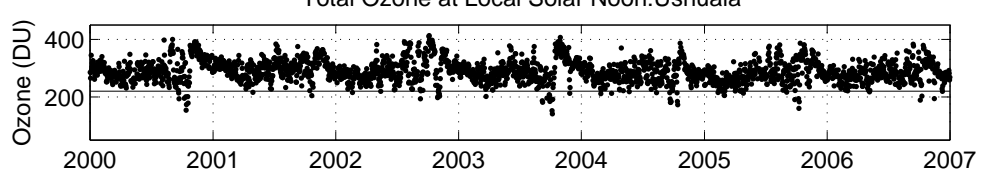

Daily Maximum UV Index:Ushuaia
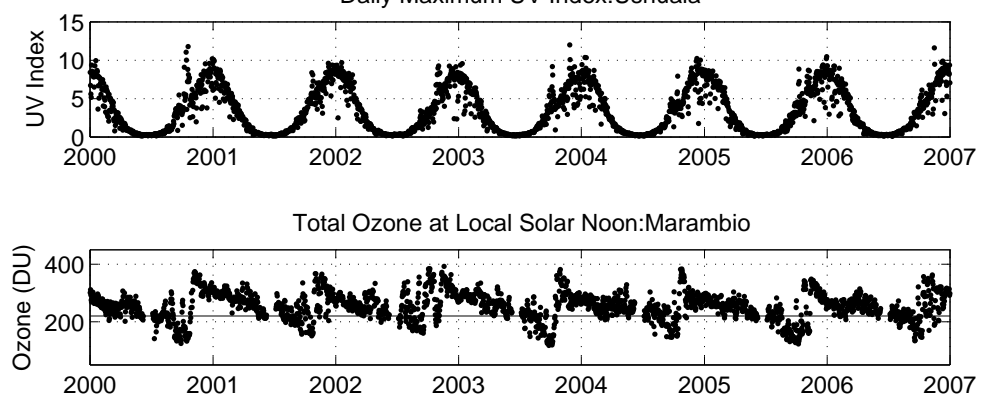

Fig. 2. Time series of total ozone and UV index at Ushuaia, Marambio and Belgrano-II during 2000-2006. Horizontal line in ozone plots indicate the level Ozone hole level off 220 Dobson Units. 

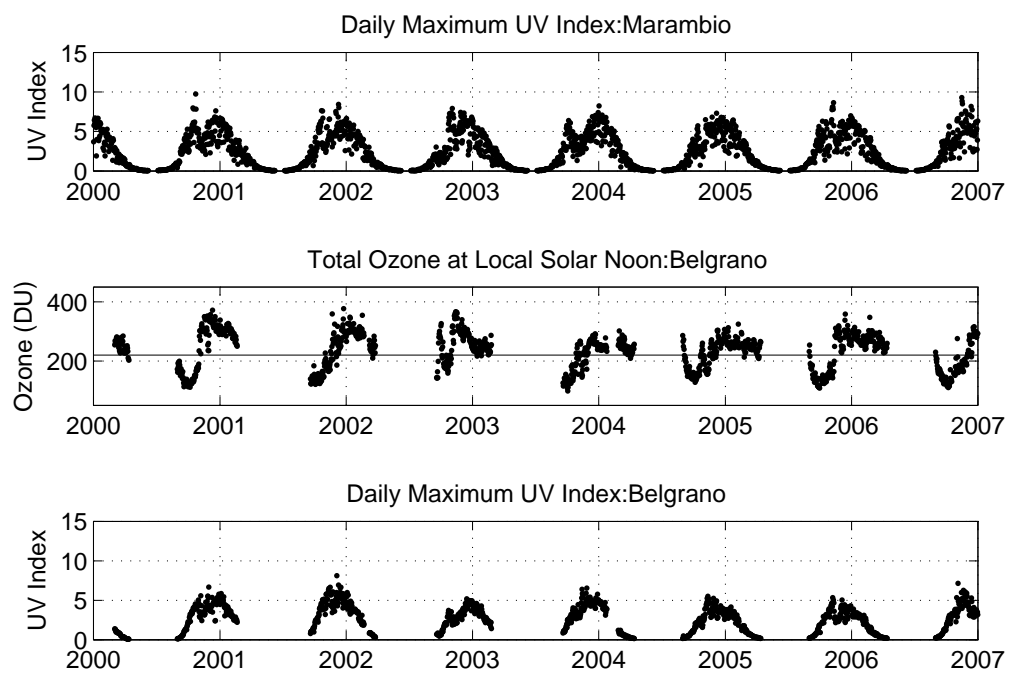

Fig. 2. Continued.
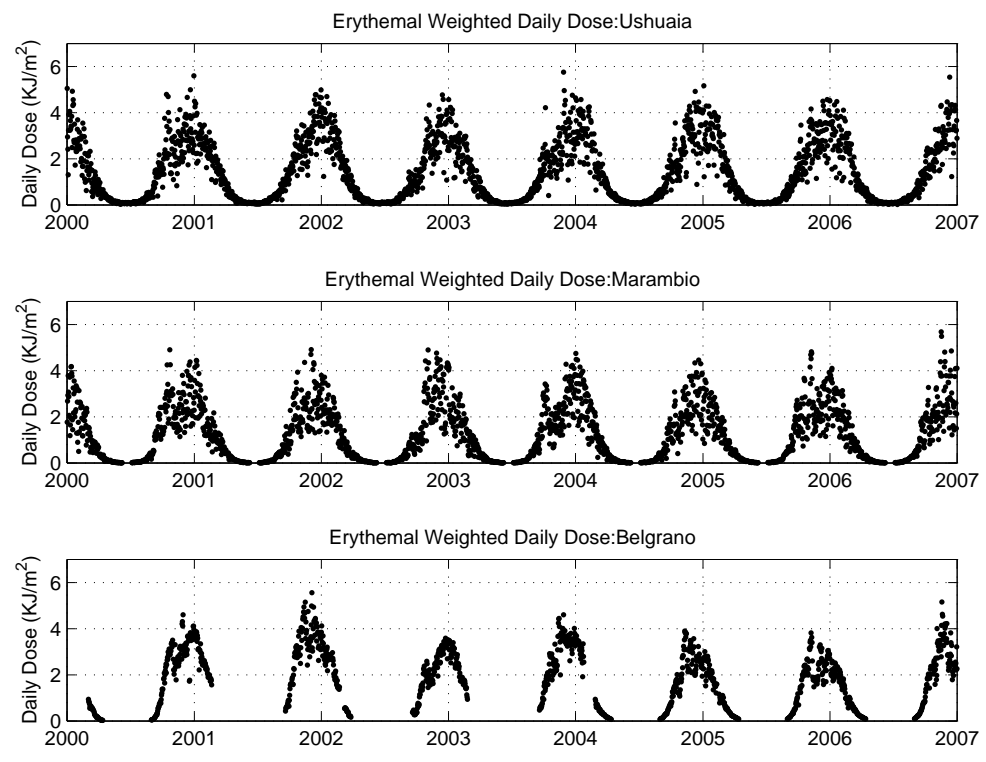

Fig. 3. Time series of Erythemal Daily Dose Ushuaia, Marambio and Belgrano-II during 20002006. 